\title{
Study of prostatic pathology and its correlation with prostate specific antigen
}

\author{
Hirachand $\mathrm{S}^{1}$, Dangol UMS ${ }^{2}$, Pradhanang $\mathrm{S}^{1}$, Acharya $\mathrm{S}^{1}$ \\ ${ }^{I}$ Department of Pathology, Kathmandu Medical College and Teaching Hospital, Kathmandu, Nepal. \\ ${ }^{2}$ Department of Surgery, Kathmandu Medical College and Teaching Hospital, Kathmandu, Nepal.
}

\section{Keywords: \\ Benign prostatic hyperplasia; \\ Prostatic cancer; Prostatic intraepithelial neoplasia; \\ Prostate specific antigen; Porstate}

\begin{abstract}
Background: Diseases primarily inflicting prostate gland are inflammation, benign prostatic hyperplasia and cancer. Prostate specific antigen is a protein produced by the cells of prostate gland. It has been widely used in the diagnosis and management of patients with prostatic cancer. The aim this study was to determine the correlation between serum prostate specific antigen level and histological findings in biopsy specimens of men with prostatic disease.

Materials and Methods: This study was carried out at Kathmandu Medical College and Teaching Hospital, department of Pathology over a period of 2 years. One hundred and twenty eight cases with prostatic lesions were included in this study. Prostate specific antigen values of these cases were recorded before the surgical process. Histology of the tissue samples collected after transurethral resection of prostate was studied and relationship with prostate specific antigen level were analyzed.

Results: Benign prostatic hyperplasia was the most common histological lesion encountered ( $\mathrm{n}=95$; $74.22 \%$ ). Prostatic adenocarcinomas were seen a decade older than those with benign lesions. Maximum number of the benign cases had the Prostate specific antigen range of $0-7 \mathrm{ng} / \mathrm{ml}$. Most of the prostatic intraepithelial neoplasia lesions were seen within the PSA range of $0-7 \mathrm{ng} / \mathrm{ml}$ and adenocarcinoma in the range of $>20 \mathrm{ng} / \mathrm{ml}$.

Conclusion: Prostate specific antigen is specific for the prostate but not for prostate cancer. Both benign and malignant lesions in prostate can cause increase in serum prostate specific antigen levels, but the chances of malignancy it rising level.
\end{abstract}

\section{INTRODUCTION}

Prostate is fibromusculoglandular organ encircling the neck of the urinary bladder. So, enlargement of prostate either due to nodular hyperplasia, prostatic intraepithelial neoplasia or adenocarcinoma may give rise to bladder outlet

\footnotetext{
Correspondence:

Dr. Suspana Hirachand, MBBS,MD

Department of Pathology

Kathmandu Medical College and Teaching Hospital, Kathmandu, Nepal

E-mail:suspi1974@hotmail.com
}

obstruction. ${ }^{1,2}$ The incidence of prostatic lesions increases with increasing age. In the aging male, there is significant tissue remodeling taking place within the prostate. It was postulated that the growth is the result of a disturbed balance between apoptotic and proliferative activities with net reduction in apoptotic activity. Histologic analysis showed a decreased apoptotic activity in glandular and basal epithelial cells of the prostate. Thus, with increasing age there is a tendency of increasing prostatic volume.$^{3-5}$ Of the diseases which affects the prostate the most frequently encountered 
Table 1: Age distribution of various prostatic lesions.

\begin{tabular}{|c|c|c|c|c|c|c|}
\hline Age group & BPH & BPH with prostatitis & LGPIN & HGPIN & Adenocarcinoma & Total n (\%) \\
\hline$\leq 50$ & 2 & 0 & 0 & 0 & 0 & $2(1.56)$ \\
\hline $51-60$ & 18 & 2 & 0 & 1 & 0 & $21(16.41)$ \\
\hline $61-70$ & 35 & 3 & 3 & 3 & 3 & $47(36.72)$ \\
\hline $71-80$ & 30 & 2 & 2 & 4 & 5 & $43(33.59)$ \\
\hline $81-90$ & 10 & 0 & 0 & 0 & 5 & 15(11.72) \\
\hline Total & 95 & 7 & 5 & 8 & 13 & $128(100)$ \\
\hline
\end{tabular}

BPH: Benign prostatic hyperplasia, LGPIN: Low grade prostatic intraepithelial neoplasia, HGPIN: High grade prostatic intraepithelial neoplasia

Table 2: Correlation of PSA level and various prostatic lesions

\begin{tabular}{ccccccc}
\hline $\begin{array}{c}\text { PSA level (ng/ } \\
\text { ml) }\end{array}$ & BPH & BPH with prostatitis & LGPIN & HGPIN & Adenocarcinoma & Total (\%) \\
\hline $0-7$ & 81 & 5 & 4 & 4 & 0 & $94(73.43 \%)$ \\
$7.1-14$ & 8 & 2 & 1 & 3 & 0 & $14(10.93 \%)$ \\
$14.1-21$ & 2 & 0 & 0 & 1 & 1 & $4(3.13 \%)$ \\
$21.1-28$ & 3 & 0 & 0 & 0 & 0 & 4 \\
$28.1-35$ & 1 & 0 & 0 & 0 & 3 & $4(3.13 \%)$ \\
$>35$ & 0 & 0 & $\mathbf{5}$ & $\mathbf{8}$ & 8 & $8(6.25 \%)$ \\
Total & $\mathbf{9 5}$ & $\mathbf{7}$ & & & $\mathbf{1 3}$ & $\mathbf{1 2 8}(\mathbf{1 0 0} \%)$ \\
\end{tabular}

in clinical practice are benign prostatic hyperplasia, prostatic cancer and prostatitis. ${ }^{6}$ Prostate specific antigen (PSA), a glycoprotein serine protease, was first identified by Wang et al. in $1979 .{ }^{7}$ Prostate specific antigen (PSA) is a widely used tumor marker for prostatic cancer. ${ }^{8,9}$ It is well known that PSA is prostatic specific, not a disease specific marker. PSA level can increase in nonmalignant conditions like benign prostatic hyperplasia, inflammation, diagnostic and surgical procedures. These conditions can mimic cancer and cause confusion in diagnosing especially in prostatic carcinoma where PSA is used as a screening test. ${ }^{10}$

Hence, this study was undertaken to determine the correlation between serum PSA level and histological findings in biopsy specimens of men with prostatic disease.

\section{MATERIALS AND METHODS}

This is a prospective study carried out from October 2014-September 2016 ( 2 years) in the department of Pathology, Kathmandu Medical College and teaching Hospital, Kathmandu, Nepal. This study included 128 cases with prostatic lesions. PSA values of these cases were recorded before the surgical process. Serum PSA levels were estimated using chemiluminescent assay. Transurethral resection of prostate (TURP) biopsies were fixed in formalin (10\%), processed and stained with Haematoxylin and Eosin for histopathological examination. Diagnostic criteria for benign prostatic hyperplasia (BPH), prostatitis, Prostatic intraepithelial neoplasia (PIN), and adenocarcinoma were adapted from guidelines laid down by World Health Organization (WHO) 2004.

\section{RESULTS}

The present study constituted a total of 128 cases, age ranged from 46 to 88 years (mean 68 years) diagnosed with benign (BPH and BPH with prostatitis), premalignant (LGPIN and HGPIN) and malignant (adenocarcinoma prostate) lesions of prostate. Maximum number of cases $(n=47 ; 36.72 \%)$ were in the age group of 61-70 years followed by 71-80 years age group $(n=43 ; 33.5 \%)$. Only 2 cases $(1.56 \%)$ were observed younger than 50 years of age.

Out of 128 cases, 95 (74.22\%) were of BPH followed by prostatic intraepithelial neoplasia, adenocarcinoma prostate and prostatitis.(Table1)

Benign prostatic hyperplasia (BPH) was the most common histological lesion encountered $(n=95 ; 74.22 \%)$ with maximum incidence seen in 61-70 age group (35 cases). (Table 1)

Prostatic adenocarcinoma was seen a decade older than those with benign lesions. PSA values were classified into intervals of $7 \mathrm{ng} / \mathrm{ml}$. The number of lesions, when correlated with PSA, showed maximum number of cases $(n=94$; $73.43 \%$ ) in PSA range of $0-7 \mathrm{ng} / \mathrm{ml}$. (Table 2)

Maximum numbers of the benign cases (BPH and BPH with prostatitis) were seen in the PSA range of $0-7 \mathrm{ng} / \mathrm{ml}$. Most of the PIN lesions were seen within the PSA range of $0-7 \mathrm{ng} / \mathrm{ml}$ and adenocarcinoma in the range of $>20 \mathrm{ng} / \mathrm{ml}$. The results of comparison of serum PSA levels in benign and malignant lesions reveal positive correlation between the increase in 
PSA levels and malignant lesions. The rising PSA levels are associated with higher chances of malignant lesions.

\section{DISCUSSION}

Prostatism is common in the geriatric age group. Benign prostatic hyperplasia and carcinoma of the prostate are increasingly frequent with advancing age and are uncommon before the age of 40 years. A careful examination of the prostate in an unselected series of autopsies disclosed nodular hyperplasia in approximately $20 \%$ of the men in 40 years of age, a figure that increases to $70 \%$ by age 60 and to $90 \%$ by eighth decade of life. ${ }^{11}$ As men age there is increased incidence of lower urinary tract symptoms. Both BPH and prostatic carcinoma present with obstructive urinary symptoms. Benign prostatic hyperplasia is characterized pathologically by cellular proliferation of epithelial and stromal elements in the prostate gland. These changes results in increased resistance to urinary flow during micturition, which was also seen in our study as the chief complaint of patients.

In our study, age group afflict with prostatic pathology was 46-88 years with mean age of 68 years, similar to studies done by Josephine A, Mansoor I, Lakhey M et al., and Lokuhettty MD et al. (mean age 65.5, 65.55, 67.61, 69.7 years). ${ }^{10,12-14}$ This study shows $79.69 \%$ of the cases as benign (BPH, BPH with prostatitis) while $20.31 \%$ of cases malignant (PIN, adenocarcinoma). Similar studies done by Puttaswamy et al. and Benerjee B et al. also encountered benign lesions constituting $80.6 \%, 75 \%$ and malignant lesions constituting $19.4 \%, 25 \% .{ }^{15,16}$

Benign prostatic hyperplasia was the most common histological lesion encountered (95 cases-74.22\%) in our study with maximum incidence seventh decade, and this is in concordance with studies done by Lakhey $\mathrm{M}$ et al $(65.33 \%)$, Josephine A et al(74.52\%), and Vani BR et al $(70.8 \%))^{10,12,17}$

In our study we found $10.16 \%$ of PIN lesions, similar as study done by Banerjee B et al (10\%) and Maru AM et al $(10.99 \%){ }^{16,18}$ In a study done by Shakya et al. they found only $1.88 \%$ of PIN lesions. ${ }^{19}$ The higher incidence of PIN lesions in our study may be due to the fact that most of the diagnosed lesions were in TURP specimens where the entire part of gland is sampled and examined under microscope thus allowing more chances of diagnosing PIN as it may occur in small foci within a gland, which might go unnoticed in a biopsy, hence limiting the usefulness of prostatic biopsy.

The incidence of prostatic adenocarcinoma was $10.16 \%$ in our study, which correlates with studies done by Banerjee B et al. and Wadgaonkar AR et al, where they reported 15\% malignant cases in their studies. ${ }^{16,20}$
Prostate specific antigen is secreted exclusively by prostatic epithelial cells. In several disease processes such as BPH, prostatitis, PIN and cancer, serum PSA level is increased. From $30-50 \%$ of patients with benign prostatic hyperplasia have elevated serum PSA concentrations, depending on the size of the prostate and degree of obstruction, and in prostatic cancer the concentration is increased in 20-92\% of patients, depending on the tumor volume. Measurement of the serum PSA is the most sensitive marker available for monitoring the progression of prostatic cancer. ${ }^{21}$ PSA is specific for prostatic tissue, but not specific for prostatic cancer. Umbehr MH et al. and Kiehl R et al. in their studies concluded that BPH and prostatitis is associated with high serum PSA, when glandular epithelium is disrupted. ${ }^{22,23} \mathrm{On}$ the other hand, Papsidero LD et al. suggested that elevation of PSA is due to unknown substances released by epithelial cells in association with the inflammatory processes surrounding the affected area. ${ }^{24}$ In our study most of the patients with benign pathology had PSA in range of 0-7 ng/ $\mathrm{ml}(73.43 \%)$, while $26.57 \%$ had PSA level above $7 \mathrm{ng} / \mathrm{ml}$ owing to the probable fact as mentioned above.

In our study LGPIN and HGPIN were seen in $13(10.16 \%)$ out of 128 cases. The PSA levels in 8cases (61.54\%) were in range of $0-7 \mathrm{ng} / \mathrm{ml}$, and in rest of the 5 cases PSA levels were $>7 \mathrm{ng} / \mathrm{ml}$. Prostatic adenocarcinoma were seen in 13 cases $(10.16 \%)$ with PSA levels $>20 \mathrm{ng} / \mathrm{ml}$. Studies done by Lekili $\mathrm{M}$ et al., Kamleshwaran KK et al. and Banerjee B et al. also found the serum PSA levels $>20 \mathrm{ng} / \mathrm{ml}$ in prostatic adenocarcinoma. ${ }^{16,25,26}$ An increasing PSA levels implies underlying malignancy and more so of a high grade as evidence with significant relationship between PSA level and histopathology, especially when PSA level was more than $20 \mathrm{ng} / \mathrm{ml}$.

\section{CONCLUSION}

In conclusion benign prostatic hyperplasia is the most common pathology encountered in prostatic specimens. PSA is specific for prostatic tissue and is raised in both benign and malignant lesions of prostate. But the chances of malignancy increases with rising value of PSA.

\section{REFERENCES}

1. Kantikundo SNS, Bhattacharyya NK, Bhattacharyya PK, Kundu AK. A study to correlate histopatholgy, biochemical marker and immunohistochemical expression of sex-steroid receptor in prostatic growth. Indian J Med Paediatr Oncol 2014;35:40-3. Crossref

2. Begum Z, Attar AH, Tengli MB, Ahmed MM. Study of various histopathological patterns in TURP specimens and incidental detection of carcinoma prostate. Indian J Pathology and oncology 2015;2:303-8. Crossref

3. Briganti A, Capitanio U, Suardi N, Gallina A, Salonia A, Bianchi M. Benign prostatic hyperplasia and its etiologies. Eur Urol Suppl 2009; 8: 865-871. Crossref

4. Untergasser G, Madersbacher S,Berger P. Benign prostatic hyperplasia: age related tissue remodeling. Exp Gerontol 2005; 40: 121-128. Crossref 
5. Konwar R, Chattopadhyay N, Bid HK. Genetic polymorphism and pathogenesis of benign prostatic hyperplasia. BJU Int 2008;102:53644. Crossref

6. Cotran RS, Kumar V, Robbins SI. Prostate. Robbins Pathologic Basis of Disease, 6th ed., Philadelphia: Saunders Co.,1994. pp.1025-34.

7. Wang MC, Valenzuela LA, Murphy GP, Chu TM. Purification of human prostate specific antigen. Invest Urol 1979;17:159-63. Crossref

8. Pinsky PF, Kramer BS, Crawford ED, Grubb RL, Urban DA, Andriole GL, et al. Prostate volume and prostatic specific antigen levels in men enrolled in a large screening trial. Urology 2006;68:352-6. Crossref

9. Fitzpatrick JM. PSA measurement in the treatment of BPH. BJU Int. 2004;93:2-4. Crossref

10. Lakhey M, Ghimire R, Shrestha R, Bhatta AD. Correlation of serum free prostate- specific antigen level with histological findings in patients with prostatic disease. Kathmandu Univ Med J 2010;8:15863. Crossref

11. Bid HK, Konwar R, Singh V. Benign prostatic hyperplasia; is it a growing public health concern for India? Indian J Med Sci 2008;62:373-4. Crossref

12. Josephine A. Clinicopathological study of prostatic biopsies. J Clin Diagn Res 2014;8:4-6. Crossref

13. Mansoor I. Pattern of prostatic diseases in Saudi Arabia. The internet journal of Pathology. TMISSN 2003;2:1528-8307.

14. Lokuhetty MD, Wijsinghe HD, Abeysuriya DT, Samarasinghe UC. Transrectal ultrasound guided prostatic biopsies: a single centre experience in Sri Lanka. Ceylon Med J 2009;54:6-9. Crossref

15. Puttaswamy K, Parthiban R, Shariff S. Histopathological study of prostatic biopsies in men with prostatism. J Med Sci Health 2016;2:11-17

16. Banerjee B, Iqbal BM, Kumar H, Kambale T, Bavikar R. Correlation between prostate specific antigen levels and various prostatic pathologies. J Med Soc 2016;30:172-5. Crossref

17. Vani BR, Kumar D, Sharath BN, Murthy VS, Geethamala K. A comprehensive study of prostate pathology in correlation with prostatic specific antigen levels: An Indian study. Clin cancer Investing J 2005;4:617-20. Crossref
18. Maru AM, Makwana HH, Lakum NR, Chokshi T, Agnihotri A, Trivedi N, et al. Study on correlation between prostate specific antigen and various prostatic pathology. Int J Med Sci Public Health 2014;3:735-7. Crossref

19. Shakya G, Malla S, Shakya KN. Salient and co-morbid features in benign prostatic hyperplasia: A histological study of the prostate. Kathmandu Univ Med J 2003;1:104-9.

20. Wadgaonkar AR, Patil AA, Mahajan SV, Yengantiwar RP. Correlation of serum prostate specific antigen level in various prostatic pathology in elderly men. Int J Basic Appl Med Sci 2013;3:274-81.

21. William JC, Deborah SS, Timothy LR et al. Measurement of prostatic specific antigen in serum as a screening test for prostatic cancer. $\mathrm{N}$ Engl J Med 1991;324:1156-61. Crossref

22. Umbehr MH, Gurel B, Murtola TJ et al. Intraprostatic inflammation is positively associated with serum PSA in men with PSA $<4 \mathrm{ng} /$ $\mathrm{ml}$, normal DRE and negative for prostate cancer. Prostate Cancer Prostatic Dis 2005;18:264-9. Crossref

23. Kiehl R, Lemos LD, Stavale JN, Ortiz V. Correlation between histologic grading and serum prostatic specific antigen in prostatic carcinoma. Int Urol Nephrol 1994;26:665-8. Crossref

24. Papsidero LD, Kuriyama M, Wang MC et al. Prostate antigen: a marker for human prostate epithelial cells. J Natl Cancer Inst 1981;66:37-42. Crossref

25. Lekili M, Zengin M, Postaci H, Ayder AR. Relationship between histologic grading and serum prostate specific antigen in prostatic carcinoma. Int Urol Nephrol1994;26:665-8. Crossref

26. Kamaleshwaran KK, Mittan BR, Harisankar CN, Bhattacharya A, Singh SK, Mandal AK. Predictive value of serum prostate specific antigen in detecting bone metastasis in prostate cancer patients using bone scintigraphy. Indian J Nucl Med 2012;27:81-4. Crossref 